\title{
P. MAURITIUS PÖHM AND HIS CONTRIBUTION TO MUSICAL LIFE IN NOVO MESTO DURING THE SECOND HALF OF THE EIGHTEENTH CENTURY
}

\author{
RADOVAN ŠKRJANC \\ Muzikološki inštitut ZRC SAZU
}

\begin{abstract}
Izvleček: Prispevek predstavlja nekaj najpomembnejših ugotovitev raziskave t. i. Pöhmovih muzikalij v Novem mestu. P. Mavricij Pöhm, frančiškan in organist, se je rodil na Češkem leta 1745. Pozneje je deloval v več samostanih $v$ slovenskem in hrvaškem delu nekdanje frančiškanske province sv. Križa, kjer je tudi umrl leta 1803. Njegovo češko poreklo in sloves izvrstnega glasbenika je zgodovinarje v preteklosti spodbudilo na eni strani $k$ domnevi o odločilni vlogi p. Pöhma pri oblikovanju glasbenega repertoarja $v$ Novem mestu $v$ drugi polovici 18. stoletja, na drugi strani pa $k$ domnevi, da je bil prav Pöhm oseba, ki je novomeški samostan oskrbela s številnimi glasbenimi rokopisi s Češkega. Omenjena raziskava je obe domnevi preverila, prvič, z vidika dejanskega obsega muzikalij v novomeškem samostanu, ki jih je mogoče zanesljivo povezovati z delom $p$. Pöhma $v$ njem, in drugič, z ugotavljanjem geografskega izvora papirja, na katerem je glasba napisana.
\end{abstract}

Ključne besede: glasbeni repertoar, Novo mesto, frančiškani, 18. stoletje.
Abstract: The paper presents some of the most significant results of research on the so-called Pöhm music collections in Novo mesto (Ger. Rudolfswerth, Lat. Neostadium). P. Mauritius Pöhm, born in Bohemia in 1745, was a Franciscan friar and organist. He was later active in several monasteries in the Slovenian and Croatian regions of the former Franciscan province of the Holy Cross, where he died in 1803. His Bohemian roots and his high reputation as a musician have led some scholars in the past to assume, first, that Pöhm played a decisive role in the formation of the musical repertory in Novo mesto during the second half of the eighteenth century, and, second, that he personally obtained numerous music manuscripts preserved in Novo mesto from Bohemia. Both conjectures have been re-examined in the course of the present research - with a view to discerning the real extent of the music in this repertory that can convincingly be linked to Pöhm personally, and also to establishing its geographical origin through a study of the paper on which the manuscripts were written.

Keywords: music repertory, Novo mesto, Franciscans, eighteenth century.

The name of Mauritius Pöhm has been known to modern historians ever since the mid1960s, when two important music collections were brought to light in Novo mesto (Ger. Rudolfswerth, Lat. Neostadium) during a stocktaking of old musical manuscripts and prints 
on Slovenian territory. ${ }^{1}$ When added to the less comprehensive collection of music from the second half of the eighteenth and the beginning of the nineteenth century held by the local chapter church, the collection in the Franciscan monastery at Novo mesto supplements in an important way our knowledge of eighteenth-century music in the Slovenian lands, with regard not only to the art of composition cultivated by native-born musicians at that time, but also to the musical repertoire that reached the Slovenian provinces from other parts of Europe.

The monastery's collection contains over five hundred archival units comprising various vocal and/or instrumental church works and compositions for keyboard instruments, as well as a wide range of music for string, or other instrumental, chamber ensembles. ${ }^{2}$ Another essential characteristic that distinguishes this collection and sets it apart from comparable music collections on Slovenian soil (in Celje, Ptuj, Ljubljana and Maribor, as well as Koper and Piran) is the very wide range of composers represented. The music from the eighteenth century that it contains consists mainly of works by contemporary Central European composers - whether musicians of merely local importance or widely influential Viennese and other Austrian ones - as well as numerous Czech and Bavarian masters. Alongside these, the collection also includes pieces originating from more distant European cultural centres, such as London and Paris. It naturally also contains typical examples of eighteenth-century Franciscan music, which was geographically much more limited, being disseminated in the form of so-called "choirbook" manuscripts exclusively within the monasteries of this order. ${ }^{3}$

As Janez Höfler admitted at the time of the discovery of this repertoire some fifty years ago, the diversity, up-to-dateness and, most especially, emphatically international character of this musical repertoire from eighteenth-century Novo mesto seemed, in the light of the "general cultural situation in this part of the Slovenian territory at that time [...] almost unfathomable". ${ }^{4}$ Höfler accordingly tried to find an explanation for the characteristics of the two collections from Novo mesto by focusing on the personal ambitions of musicians of the past working in Novo mesto rather than on any systematic "cultural policy" pursued by the institutions in which they were active. ${ }^{5}$

In this regard, three names come to the fore on account of their frequent appearance on the covers of the Novo mesto musical items dating from the second half of the eighteenth century. First, there are the names of two Franciscan friars: Mauritius Pöhm and Calist Weibl. The second man was born in Novo mesto in 1749 and was (also as an organist) later active in several monasteries in the Slovenian and Croatian portions of the former Franciscan province of the Holy Cross (in Novo mesto, Ljubljana, Klanjec and Trsat). ${ }^{6}$ But these items also frequently contain the name of a certain, still completely

1 Höfler, "Glasbenozgodovinske najdbe," 136.

2 See ibid., 135-148; Faganel, "Glasbeni repertoar," 120-123; Škrjanc, "Prispevek k poznavanju," 33-55.

3 See Škrjanc, "Frančiškanske korne knjige,” 65-86; Barbo, “"Cantual' brežiškega frančiškanskega samostana," 257-273.

4 Höfler, "Glasbenozgodovinske najdbe," 136.

5 Ibid.

${ }^{6}$ Ibid.; see also Kinderić, Franjevci uz orgulje, 152. 
unknown, music copyist and perhaps musician, Andreas Pitter, who must have been in close contact with Pöhm, as will be explained later.

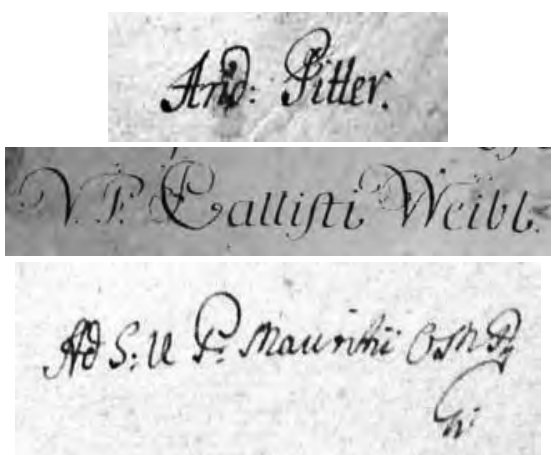

Figures 1a, 1b and 1c Inscriptions of Pitter's, Weibl's and Pöhm's names in the manuscripts SI-Nf, Ms. mus. 113a, 90 and 54a (Novo mesto, Knjižnica Frančiškanskega samostana; reproduced with kind permission).

Pöhm's name is especially interesting in connection with the creation of the repertoire under discussion. To express this more precisely: this was the name under which a musician who supposedly had a decisive impact on the musical activities of the local Franciscans in the second half of the eighteenth century signed numerous music manuscripts in Novo mesto. His Czech origin might on one hand - at least in principle - "explain the classicist orientation of the Novo mesto monastery's repertoire, characterized by the well-known German and Czech artists," as Höfler puts it. ${ }^{7}$ On the other hand, it also provides us with an opportunity to establish a link between the specific presence of musical items by Czech composers in Novo mesto and the contacts that Pöhm could have maintained with his native land after his arrival in Novo mesto or even to conclude that he brought with him from Bohemia at least a segment of these musical collections when he first arrived on Slovenian territory.

When and from exactly where Pöhm came to Novo mesto still remain unknown, since his life has not yet received any serious scholarly attention. ${ }^{8}$ What is certain is that he was living in that city from at least 1774, when he took up a teaching position at the local grammar school. He taught there until 1786, as well as serving as its prefect during the period 1784-1785. ${ }^{9}$ In 1788 he was appointed Guardian of the Franciscans in Novo mesto,

7 Höfler, "Glasbenozgodovinske najdbe," 136.

8 A more detailed investigation of Pöhm's life has recently been initiated by the author of this article. So far, this research has provided some new information about Pöhm's early life in Carniola: for instance, his residence in Kamnik in 1764. See "Tempore gubernante Provinciam A. R. P. Joanne Nepom. Tropper Min. Prov. a. 1764" (rubric “Familia Conventus Camnicensis"), preserved in Ljubljana, Knjižnica Frančiškanskega samostana. In this document Pöhm is described as a church organist ("Cleric. Org."). The same document mentions Beno Majer (1736-1818), who was likewise an important Franciscan musician working in Kamnik at that time, and was even perhaps Pöhm's music teacher ("VP. Beño Maÿr Org. instruet Novitios in cantu”).

9 Höfler, "Glasbenozgodovinske najdbe," 136. 
retaining this post up to his death in $1803 .{ }^{10}$ The necrology and other documentation of the Franciscan province of the Holy Cross also reveal that Pöhm was born in Bohemia in April 1745 and baptized with the name of Antonius, and that he was a brilliant organist and musician ("Organista, et Musicus praestantissimus"), a highly respected man among the people and a very popular friar. His funeral, which took place on Easter Sunday in April 1803, was accordingly unlike "any funeral Novo mesto had seen before."11

Besides providing other data concerning Pöhm's death and also his personality, these documents also contain mention of Pöhm's entry into the Franciscan Order in the Slovenian-Croatian Province of the Holy Cross as early as August 1763, when this province was headed by Friar Joannes Nepomucenus Tropper. ${ }^{12}$ Another indication that Pöhm lived in this province during the 1760 s - at the young age of twenty - was recently discovered by Petar Kinderić. This is the mention of a short stay by Pöhm in Samobor, Croatia, in 1769 (at this time the Samobor monastery belonged to the same province as that in Novo mesto)..$^{13}$

The two reports therefore suggest that Pöhm arrived on Slovenian and Croatian territory, respectively, earlier than has previously been supposed - a fact that naturally also raises doubts about the hypothesis that he brought with him to Novo mesto the musical items in question that included at least a few from Bohemia. In view of Pöhm's important role in building up the eighteenth-century musical repertoire of the Franciscans in Novo mesto - which, as already stated, is attested by numerous "written traces" - this repertoire needs to be re-examined with two aims: (1) to establish the precise identity of the musical items in the repertoire directly associable with Friar Pöhm, and (2) to determine their origin and the date of their creation. This research task is, however, only the starting point for a wider assessment of Pöhm's life and work that, in addition to the perusal of Slovenian archives, should also cover at least the archives of three monasteries in Croatia: at Trsat, Samobor and Klanjec, where one of only two works attributable to Pöhm has been preserved. ${ }^{14}$

${ }^{10}$ See "Chronicon conventus Neostadiensis ab Anno 1762 usque ad annum 1830: Tomus III," 524 and 575, preserved in Novo mesto, Knjižnica Frančiškanskega samostana; see also "Discretorium Conventus 1732 - $1752-1809$ " in the same library.

${ }^{11}$ See "Necrologium provincae S. Crucis Croatiae - Carniolae tam unitae, quam separatae, quondam Bosnae - Croatiae, adjunctis etiam Fratribus, qui per Sexennium in Conventus Styriae, et Carinthiae decreto Josephi II. Provincia Carniolae unitis obierunt: Ab anno 1490. [...], IX. Aprilis," preserved in Novo mesto, Knjižnica Frančiškanskega samostana.

${ }^{12}$ See "Nomina Electionis Praesidium: Ab Anno 1514; usque ad praesens Tempus" (rubric "Sub 2do Provincialatu A.R.P. Joan. Nepom. Tropper, electi 31. Julii 1763”), preserved in Ljubljana, Knjižnica Frančiškanskega samostana. See also earlier, n. 8.

${ }^{13}$ Kinderić, Franjevci uz orgulje, 102-103.

${ }^{14}$ The authorship of Pöhm's work preserved in Klanjec, Litaniae ex C con Canto (RISM 500077902), is unequivocal - on account of the inscription "Authore P: Mauritio Pöhm Franciscano" on the first page. Pöhm's authorship of the second composition (Aria de Immaculata: Aria pro Festis Pentecostalibus a Canto Solo, Violino Primo, Violino Secondo, Cornu Primo, Cornu Secondo con Organo; RISM 540000794), today preserved in Novo mesto, is less certain. Its manuscript contains an inscription, "Auth: P: M: P: F:", that is probably an abbreviation for the same "Authore P: Mauritio Pöhm Franciscano;" however, the evidence for this attribution lacks conclusive proof. 
The research proceeded in two phases: the first phase was the identification of all musical material in Novo mesto that can clearly be linked to Friar Pöhm; in the second phase, this material was examined to establish the origin of the paper on which the music was written. The findings of this phase of research are of merely comparative value, since they can in no way lead to a conclusion that a given manuscript written, for instance, on paper of Venetian origin in fact found its way into Slovenian territory from the Veneto.

Nevertheless, in combination with other known data, these findings can contribute usefully to the elaboration of various hypotheses by increasing or lowering their probability. One such datum, for example, reveals that the market for paper in eighteenth-century Carniola, hence also in Novo mesto, was mostly supplied from the 1740s onwards by regional manufacturers (especially Antonius and Dismos Nikel), and from 1760 onwards also by Thomas Cumar from Gorizia and André Müller from Radeče in Lower Styria. ${ }^{15}$ The Carniolan paper market was also partly supplied by four mills in neighbouring Carinthia: the Tengg mill in Villach (Slov. Beljak), the Weinländer mill in St. Ruprecht (Slov. Šentrupert) near Klagenfurt (Slov. Celovec) and the Šentvid mill on the Glina River, plus the famous Upper Austrian Steyer-Altmühle, especially during the period of its management by Johann Kienmoser (1750-1783). So nearly all the manuscripts of music by native-born composers dating from that period employed paper manufactured in one of the above-named mills. ${ }^{16}$ Similarly, the binding of most of the music manuscripts and prints preserved in Novo mesto, including that of items of undoubtedly foreign provenance, took place on Slovenian territory. ${ }^{17}$ At the same time, no locally produced manuscripts containing works by "external" musicians were copied on paper originating from Bohemia and Moravia - a fact of particular importance for research into the "Pöhm music collections" in Novo mesto.

Both parts of the research were accompanied by two problems: the first was the presence of several watermarks (on the examined paper) that could not be identified with any degree of certainty. The second problem was the form of the handwriting almost certainly attributable to Friar Pöhm, since there are considerable differences between individual graphemes. On one hand, this handwriting constitutes a fairly recognizable manuproprium that cannot be found in any other music collection in Slovenia. The same manuproprium was used for inscriptions on the covers of the manuscripts, stating that they were intended for Pöhm's personal use (“Ad Simplicem Usum P. Mauritii Pöhm OMR”), as well as for some manuscripts in their entirety - for example, the manuscript SI-Nf, Ms. mus. $278 \mathrm{a}$ - and for a considerable number of individual parts in other manuscripts that are written in another person's hand but whose covers feature inscriptions of the same kind.

${ }^{15}$ On paper production and commerce in eighteenth-century Carniola, see Šorn, "Starejši mlini," 92-104.

${ }^{16}$ For more information on this subject, see also Škrjanc, "Prispevek k dataciji," 42-60.

${ }^{17}$ Such as, for instance, the binding of Kobrich's six Masses op. 7 (Augsburg: Lotter, 1751), and that of Hirschbergers's collection Philomena cisterciensis (Burghausen: Luzenberger, 1743): both bindings exhibit watermarks of Antonius Nikel from around 1750. Interestingly, the soprano part of Hirschberger's collection preserved in Novo mesto contains an additional sheet of paper with Pöhm's transcription (?) of an unidentified setting of Sanctus and the verse "Te ergo quaesumus." 


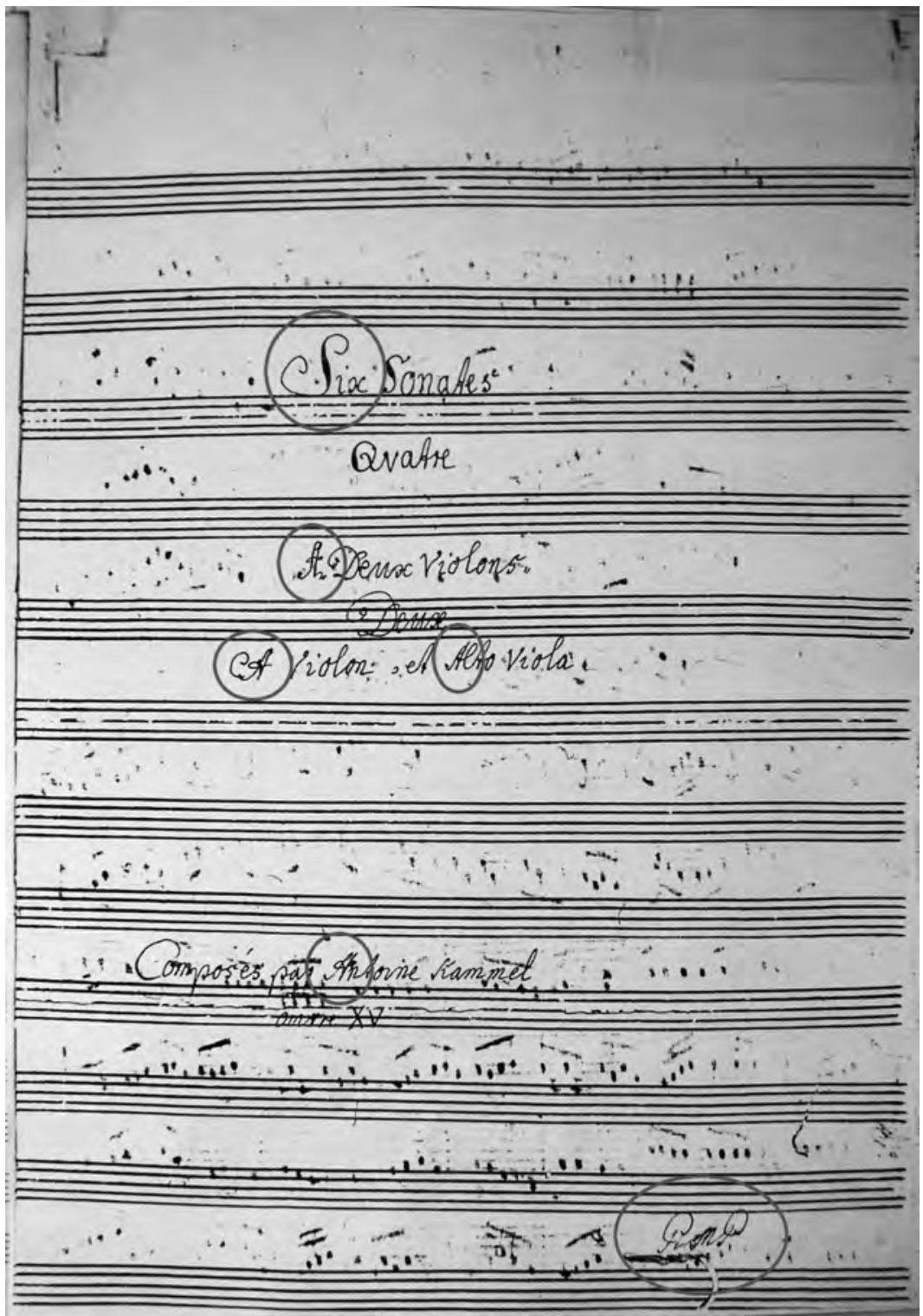

Figures 2a and 2b Pöhm's (?) handwriting in the manuscript SI-Nf, Ms. mus. 278a (Novo mesto, Knjižnica Frančiškanskega samostana; reproduced with kind permission).

One such example is the manuscript SI-Nf, Ms. mus. 115b, which was written out partly by Weibl and Pöhm, and partly by some other copyist whose identity remains unknown.

On the other hand, the material in question also contains another three manuscripts copied by Pöhm (SI-Nf, Ms. mus. 290, 291 and 418), which - like manuscript 278a display a relatively uniform handwriting. Each of these is probably also written in the 


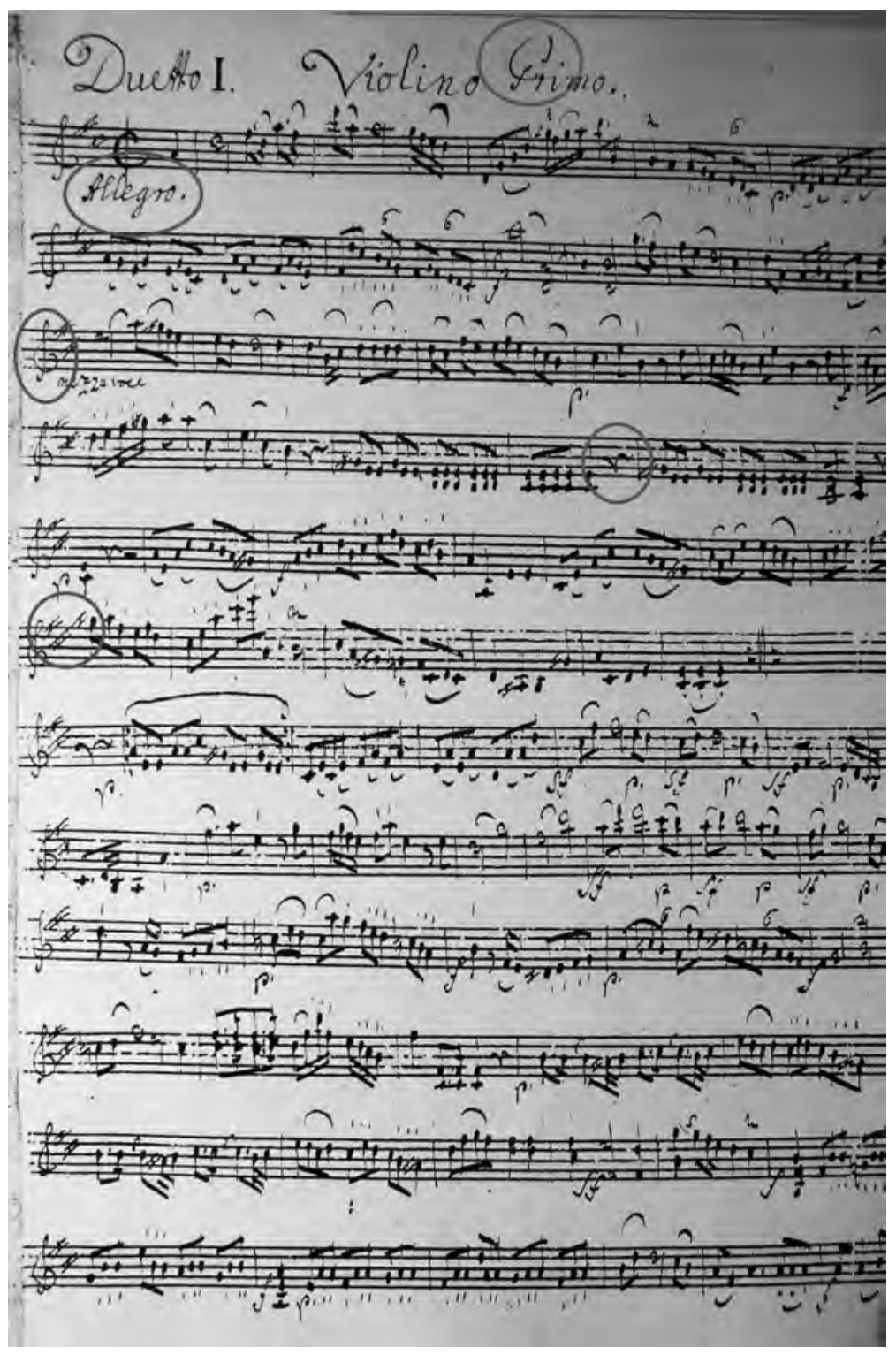

same ink and on paper from the same manufacturer. Nevertheless, these manuscripts differ considerably in their individual graphemes. And, looking at the situation from another perspective, what all these manuscripts have in common is precisely the fact that their handwriting employs graphemes different in character from those of all the other handwritings in the same archive. 


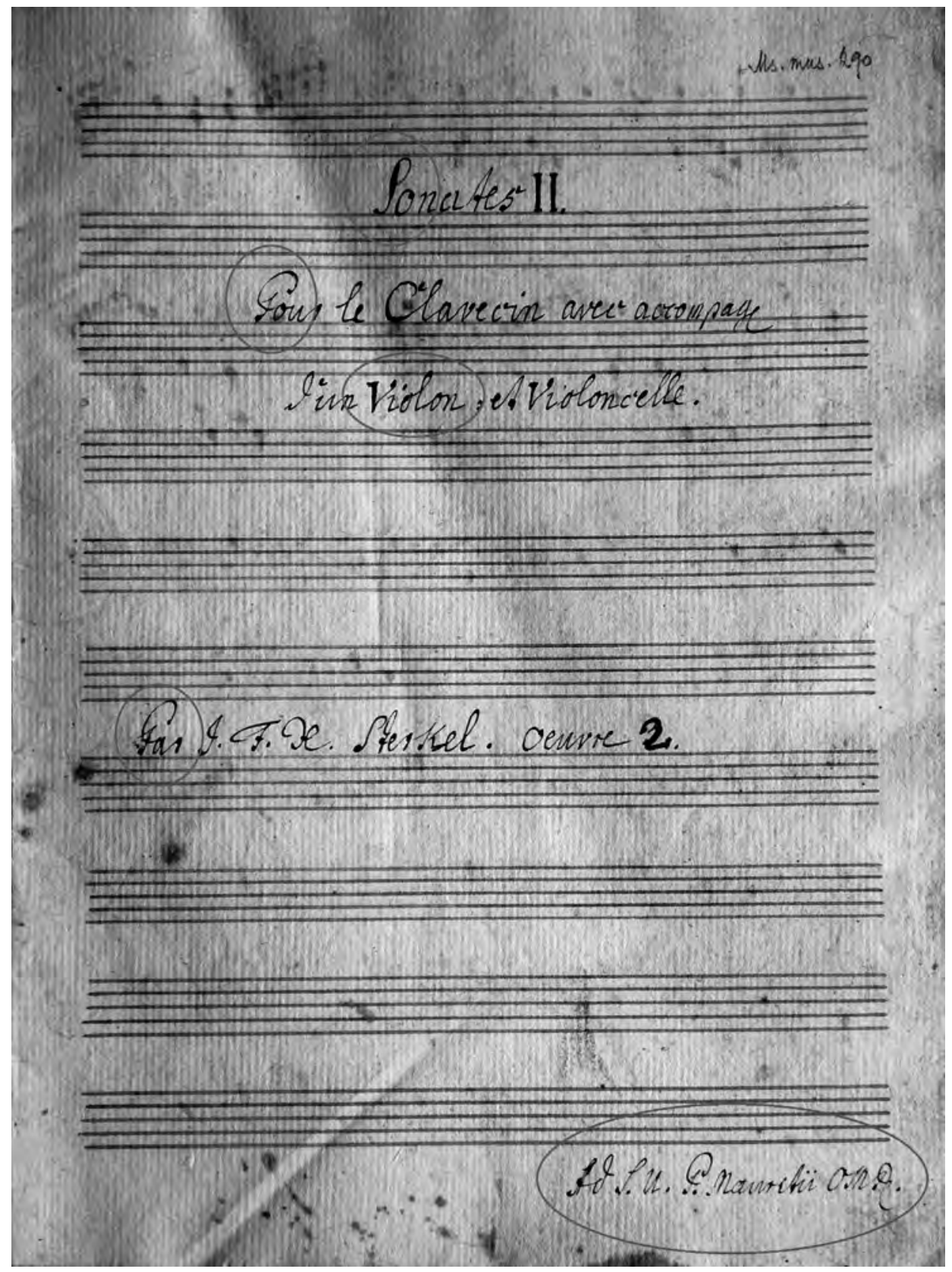

Figures 3a, 3b, 3c and 3d Different graphemes of Pöhm's (?) handwriting shown in the manuscripts SI-Nf, Ms. mus. 290 and 291 (Novo mesto, Knjižnica Frančiškanskega samostana; reproduced with kind permission). 

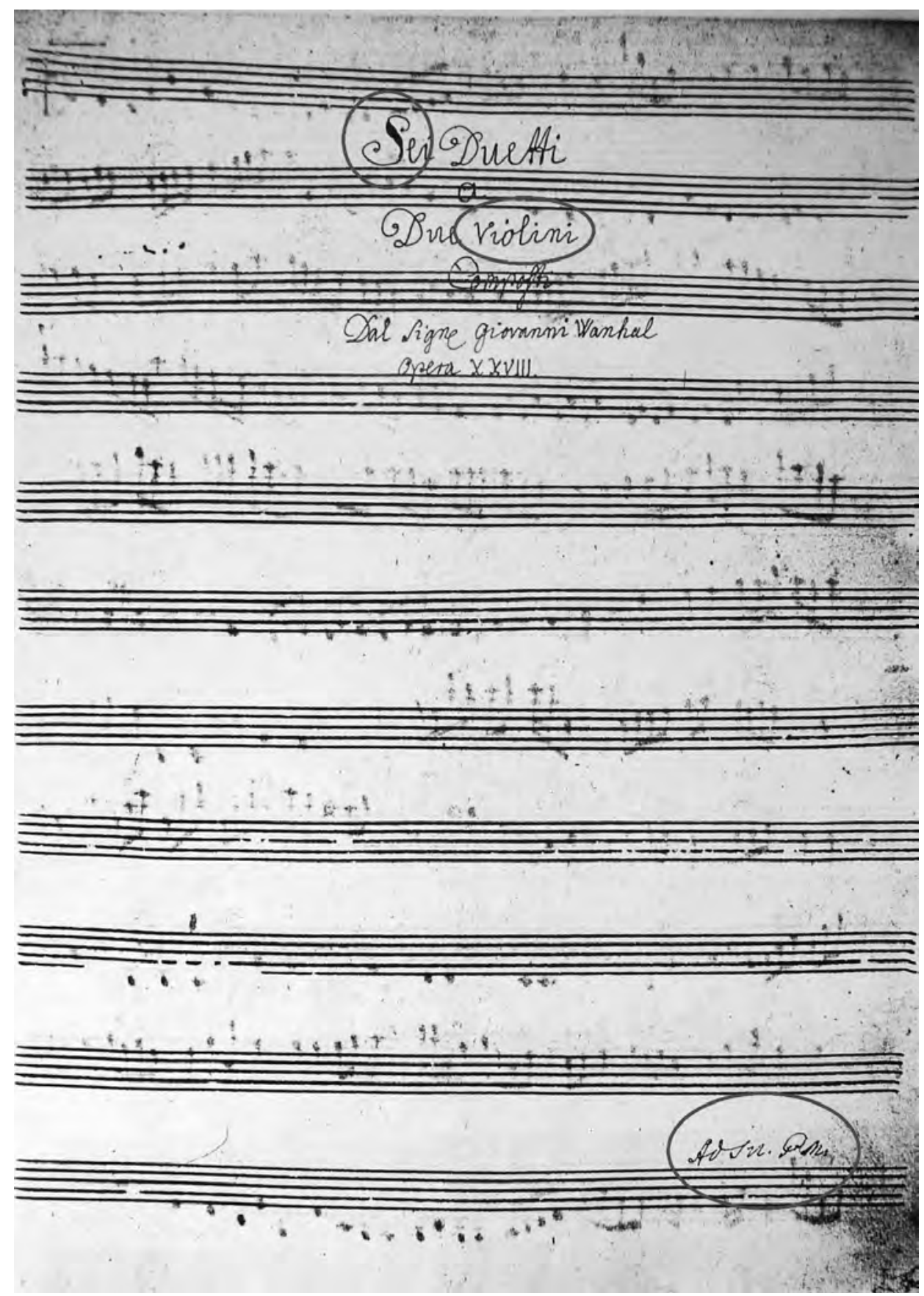


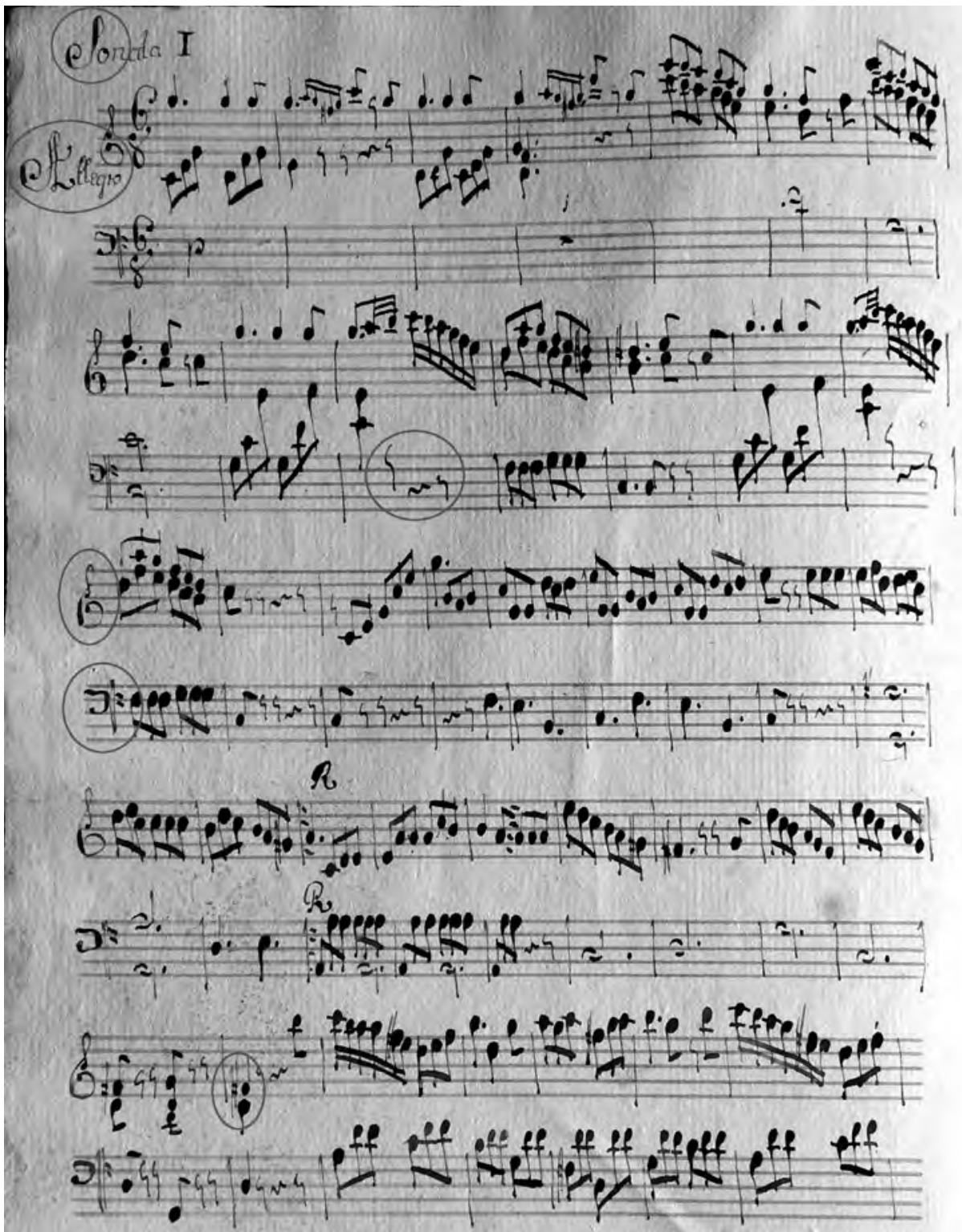


P Pllegto) Moderato.

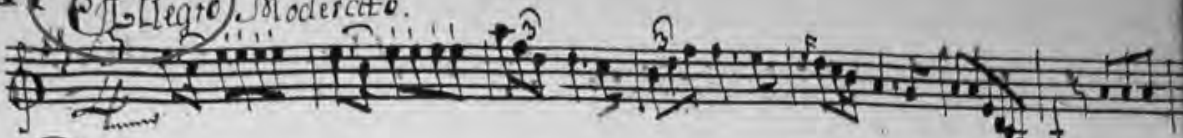

(1)

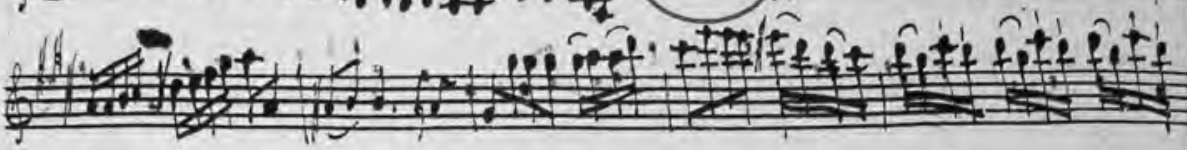

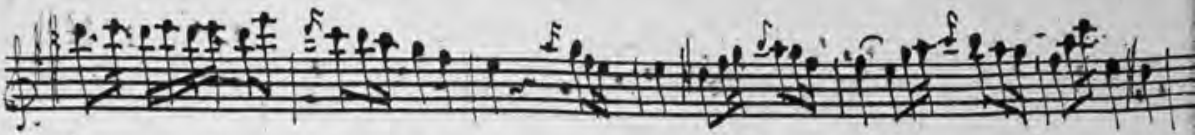

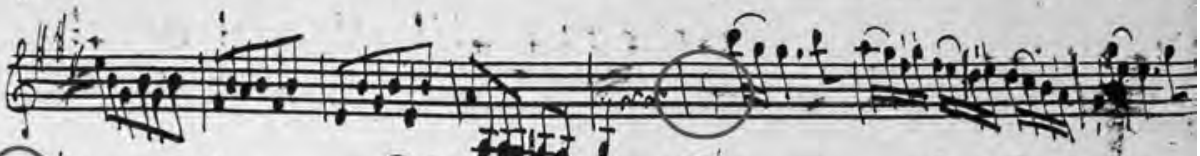
(1)

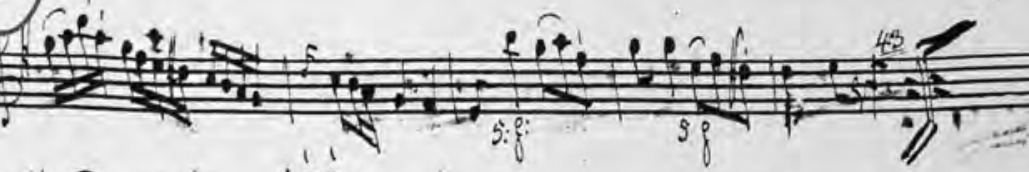

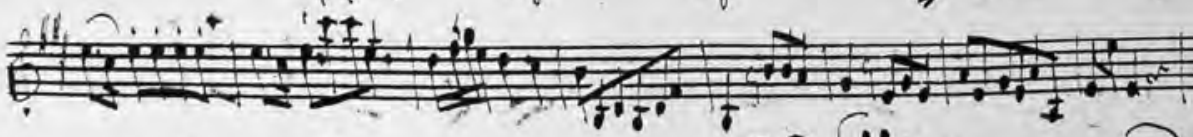

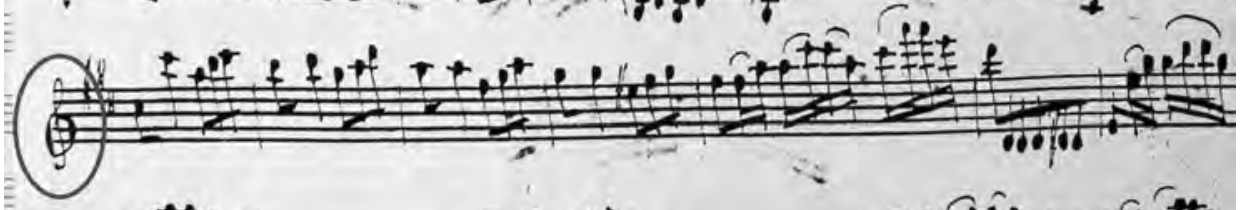
$1 \div \div \frac{71}{4}+2$

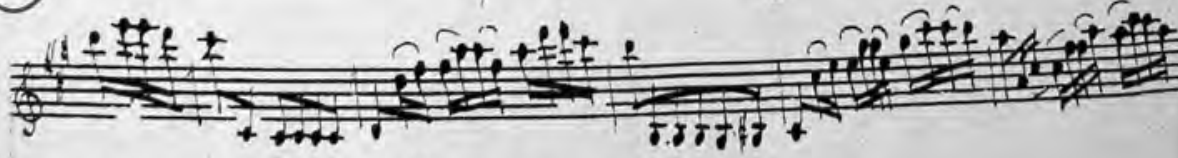

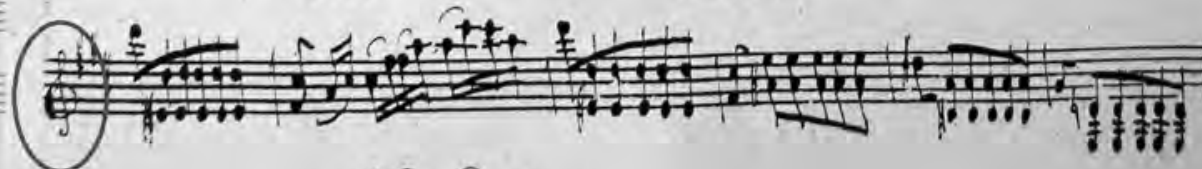


The different "faces" of this (probably one and the same) handwriting may perhaps be explained through the then customary division of the manner or, rather, style of handwriting into "conceptual" and "calligraphic" varieties - a distinction illustrated by, inter alia, the manuscripts SI-Nf, Ms. mus. 100 and 115c, both of which probably exhibit Pöhm's handwriting. To a certain extent, these differences may also be understood as the product of an evolution of handwriting over time - i.e., over the course of no fewer than thirty or perhaps even forty years (the period when Pöhm was working as a friar and musician in the Franciscan province of the Holy Cross).

There is still no definitive answer to the question concerning Pöhm's handwriting. Perhaps more will be known after the examination of other written material in the Novo mesto monastery and the music collections of the three already mentioned monasteries in Croatia. Therefore, the examined musical material in Novo mesto associable, in one way or another, with the work of Friar Pöhm, should provisionally be divided into three groups. The first group (A) comprises manuscripts that on their covers or in their separate parts contain indications of Pöhm's ownership. This group may further be divided into two subgroups (A/1 and 2 - see Table 1). The first subgroup contains fourteen manuscripts, each supplied with a label providing evidence of Pöhm's ownership of the music, which suggests that they were all very probably copied by Pöhm's hand, plus another two manuscripts $\left(^{*}\right)$ with similar inscriptions, which were jotted down on the covers by Weibl. Within this subgroup Weibl's handwriting appears on four further covers and no fewer than twenty-seven separate parts belonging to six manuscripts, where only the above-mentioned two manuscripts (i.e., 290 and 418) were copied by Pöhm, leaving aside a further eight separate parts for three other manuscripts. However, apart from specimens of Weibl's handwriting, these items also feature a number of other, unknown hands and several short inscriptions that were most likely inserted by Pöhm.

Annotations of this kind are more frequently encountered in the third (C) group of manuscripts (see Table 2). These have mostly been preserved incomplete; they contain no inscriptions with Pöhm's name but were nevertheless most probably written out by him. In addition to manuscripts with shorter or longer annotations in the same handwriting - such as in the manuscript SI-Nf, Ms. mus. 113a, produced and owned by the already mentioned copyist Andreas Pitter - this group also includes manuscripts that were perhaps partly or even wholly copied by Pöhm.

The second section of group A (see Table 1) comprises the musical items produced by Pitter, which subsequently, at an unknown date and for unknown reasons, came into Pöhm's hands. This sequence of ownership is demonstrated by the previously mentioned inscriptions on the covers, all of which are - with a single exception (the manuscript SI-Nf, Ms. mus. 127) - written over Pitter's name, which has been blotted out. Interestingly, Pöhm's handwriting did not leave any significant trace in this portion of the manuscripts, appearing only in one separate part (the basso of the manuscript SI-Nf, Ms. mus. 113b) in addition to the inscriptions affirming Pöhm's ownership. These manuscripts make up a fairly uniform group of musical items consisting mainly of secular compositions for stringed and wind instruments (only two compositions feature church music, which otherwise dominates the "Pöhm music collections" in Novo mesto). In addition to displaying Pitter's authorship, these manuscripts show an even greater degree of uniformity in respect 


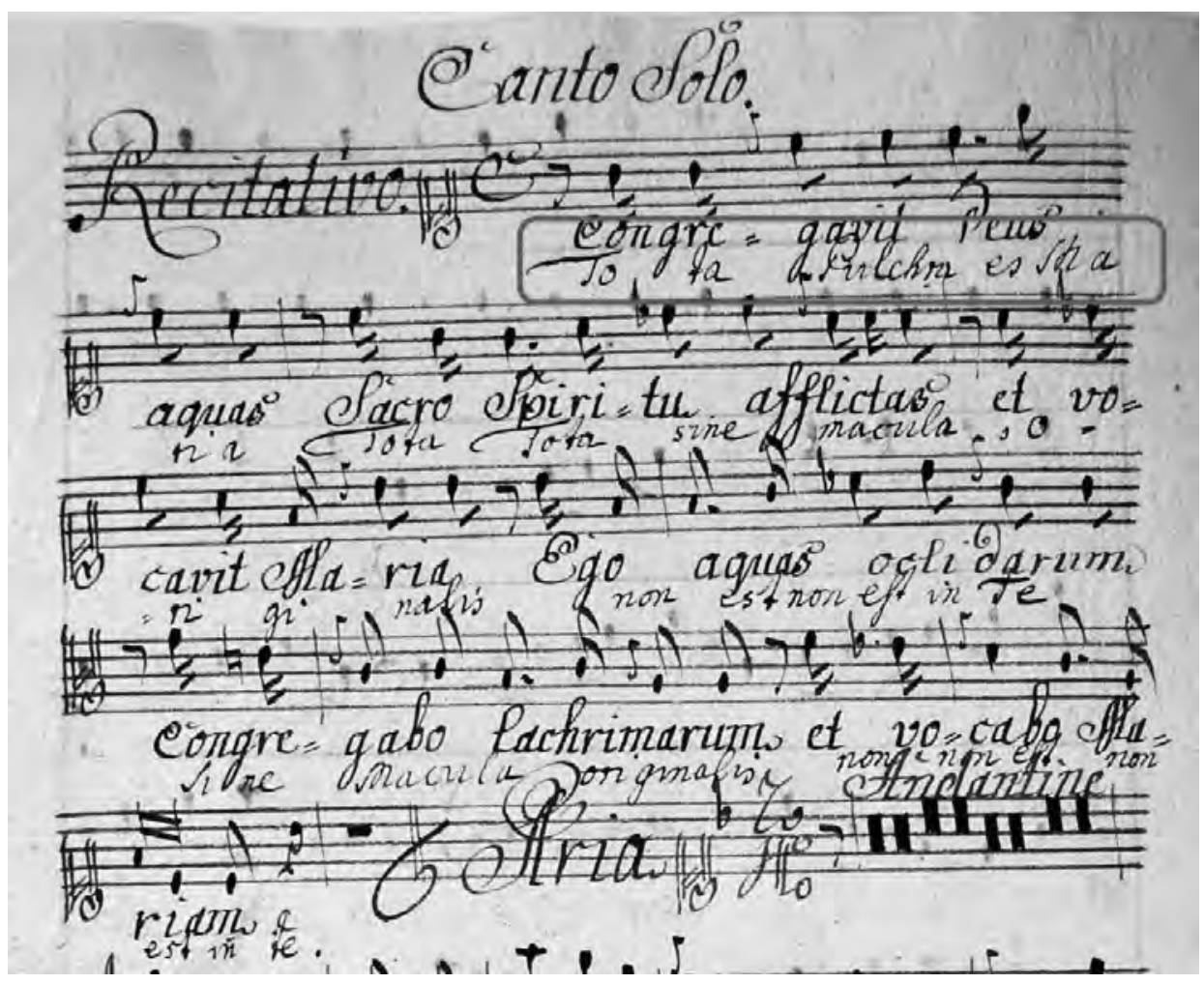

Figure 4 Pitter's handwriting and Pöhm's (?) annotations in the Canto solo part of SI-Nf, Ms. mus. 113a (Novo mesto, Knjižnica Frančiškanskega samostana; reproduced with kind permission).

of the paper on which they were written. With the exception of three items, all exhibit the type of paper that, as already stated, was dominant in Carniola between the 1760s and the 1790s (see Table 3). ${ }^{18}$ Two manuscripts (of Divertimentos for strings by Pietro Domenico Paradisi) are copied on a paper of unknown provenance bearing a watermark with three crescent moons indicative of the so-called royal paper (carta reale) manufactured in the Venetian Republic, plus the initials FA. The second watermark with these initials is linked, in Eineder's catalogue of watermarks, to a still unidentified paper manufacturer from the region of today's Lombardy. Two further unidentified watermarks occur in manuscript 113b, which - like the other manuscript containing a Paradisi divertimento - features on its cover the watermark of Thomas Cumar from Ajdovščina.

${ }^{18}$ Two principal references for identifying watermarks in the examined musical material in Novo mesto were Eineder's catalogue of watermarks for the area of the former Habsburg lands and Šorn's annotated list of watermarks employed by paper-manufacturers in Carniola during the eighteenth century. 
Most manuscripts in the second group of "Pöhm's music" or group B, except for three (SI-Nf, Ms. mus. 131, 134 and 278c), were produced on paper of similar origin. Group B contains eight items whose covers and a few separate parts feature initials that almost certainly represent Pöhm's name - this conclusion has been reached also on the basis of the inscription of both (the initials and the name in its entirety) in the manuscript SI-Nf, Ms. mus. 54a (see Table 4).

Besides the paper of two manufacturers from Carinthia and Upper Austria (Caspar von Schwerenfeld and Johann Kienmoser), which, as already noted, was used also for manuscripts belonging to group $\mathrm{A} / 2$, the manuscripts of group $\mathrm{B}$ employ that of another manufacturer from Carinthia (Georg Tengg), as well as that of Dismos Nikel from Žužemberk, which was very popular in the Slovenian territory during the 1770s (see Table 5). So despite the dominance of paper encountered also in many other manuscripts produced in eighteenth-century Carniola, group B includes four manuscripts written on paper from Italy and Moravia, and most probably also from Bohemia (the last two will be discussed in the continuation - see Tables 7a and 7b). Manuscript 278c was written on Venetian paper of the "Gava brothers" (GVA) ${ }^{19}$ and manuscript 114b on Friulian paper from

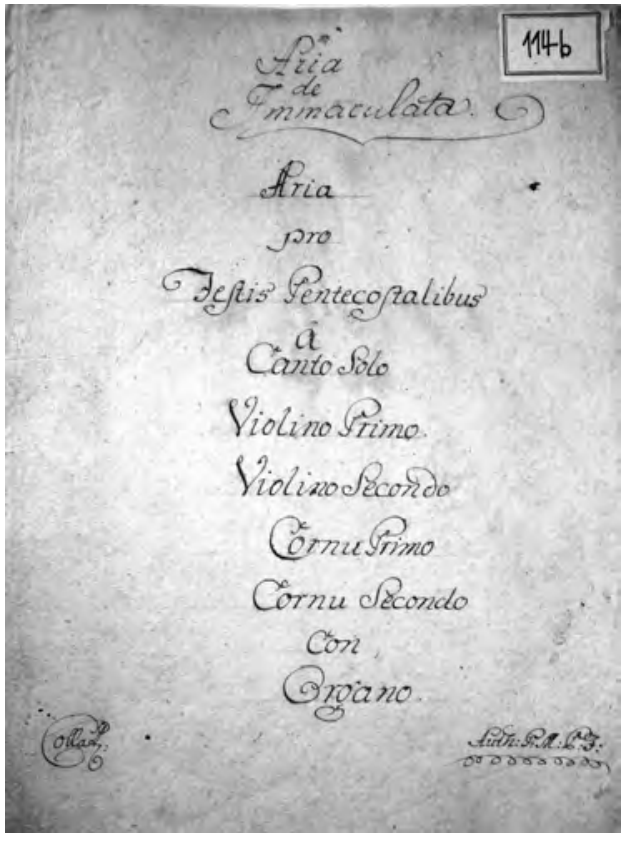

Figure 5 Title page of Pöhm's (?) Aria de Immaculata, SI-Nf, Ms. mus. 114b (Novo mesto, Knjižnica Frančiškanskega samostana; reproduced with kind permission).

the Galvani mill in Cordenons (VG). Leaving aside the separate part for soprano, which was probably copied by Pöhm, the latter was in its entirety the work of Weibl. However, it contains the only work preserved in Slovenia that may be said with any great certainty to have been composed by Pöhm. ${ }^{20}$

${ }^{19}$ See Wiesmüller, "The Watermarks," 33-34.

${ }^{20}$ See earlier, n. 14. 
Featuring the same paper and Weibl's handwriting is likewise manuscript $114 \mathrm{c}$ belonging to the first (A/1) group of manuscripts. In addition to paper with the already discussed watermarks of Kienmoser, Tengg and Nikel (see Tables 3 and 5), paper of another regional manufacturer (André Müller from Radeče) and paper with a second different watermark of Thomas Cumar, as well as paper from the mill Toscolano near Bergamo and paper of still unidentified origin (see Table 6), one of the manuscripts in group A/1 also employs Ossendorf paper from the well-known mill in Bensen, Bohemia. This is manuscript SI-Nf, Ms. mus. 416, containing Brixi’s Missa solemnis, where the manner in which the indication of the authorship of the composition is formulated suggests that it must have been copied at some point before Brixi's death in $1771 .{ }^{21}$ Another feature placing it within a period running from the end of the 1750s up to the beginning of the 1770 s is the Ossendorf watermark (see Table 7a). Moreover, the manuscript containing Brixi's composition also contains a different, unidentified watermark with the inscription SCHIL, and the letter H as countermark, which in the examined material in Novo mesto has been found in only one further document: manuscript 134 (group B). The same is true of the watermark from the Moravian mill MOHELNO, to which Eineder assigns the same year (1790) as the one written on the cover of manuscript 131, which was probably Weibl's work (see Table 7b). The separate parts in this manuscript contain numerous annotations in Pöhm's presumed handwriting and feature a different watermark originating from the Styrian mill THALBERG. The paper from that mill is used also for manuscript SI-Nf, Ms. mus. 116b, which is dated 1779 and written in its entirety in a different hand that has not been identified in any other manuscript in Novo mesto.

Finally, special mention should be made of another manuscript (SI-Nf, Ms. mus. 285) whose composition, variety of handwritings and paper types typically combine some fundamental characteristics of the so-called "Pöhm music collections" in Novo mesto. One of these characteristics is the multi-layered structure of these music collections, which in manuscript 285 - a transcription of Pleyel's String Quartets 1 from ca. 1782 - comprises three layers (see Table 8). Perhaps the oldest layer is represented by a copy of a viola part by an unknown hand on a paper bearing the letter $\mathrm{W}$ in the watermark, whose origin - to my knowledge - is still unexplained, even though this type of paper was very often used in Viennese music collections dating from the 1770s, 1780s and 1790s, as already established by Alan Tyson some time ago. ${ }^{22}$ It is also known that the Viennese paper market, as opposed to that in Carniola, was at that time mostly supplied by Venetian manufacturers, such as the previously mentioned Gava brothers, whose watermark is found, together with two other, still unidentified, watermarks, on paper used for the second part of the Novo mesto manuscript 285 . The latter was most certainly copied out by Weibl, and the same watermarks of the Gava brothers and paper featuring the letter $\mathrm{W}$ are found in the Novo mesto copy of J. C. Bach's Piano Concertos op. 7 (SI-Nf, Ms. mus. 98), made at some point after 1775, most likely in one of the copying shops then active in Vienna - like manuscript

${ }^{21}$ In this manuscript Brixi is still mentioned as an active Kapellmeister in Prague ("Auth Dmno Brixi Capellae Magistro in Area Pragensi ad S: Vitum").

${ }^{22}$ See Tyson, "Paper Studies and Haydn," 578. 
SI-Nf, Ms. mus. 97, which contains a subsequently added annotation ${ }^{23}$ indicating Pöhm's ownership. The third layer of manuscript 285 most likely consists of later copies of parts for first and second violin bearing the watermark of the regional manufacturer Thomas Cumar, which were almost certainly made by Pöhm.

To summarize: even though Pöhm's musical estate in the area of the former Franciscan province of the Holy Cross still awaits detailed research, we may safely claim that: (1) the extent of his legacy in the Novo mesto monastery is indeed vast, since of the altogether 130 musical manuscripts definitely produced before Pöhm's death in 1803, more than a quarter can be linked directly to him; (2) only a few of them may reasonably be claimed to have been brought into the Franciscan province from somewhere else (Vienna and Bohemia, perhaps also Moravia). In this regard, at least one other friar, organist and contemporary of Pöhm may have played an important part: Calist Weibl, whose musical activity (like Pöhm's) has yet to receive serious scholarly attention. 
Table 1

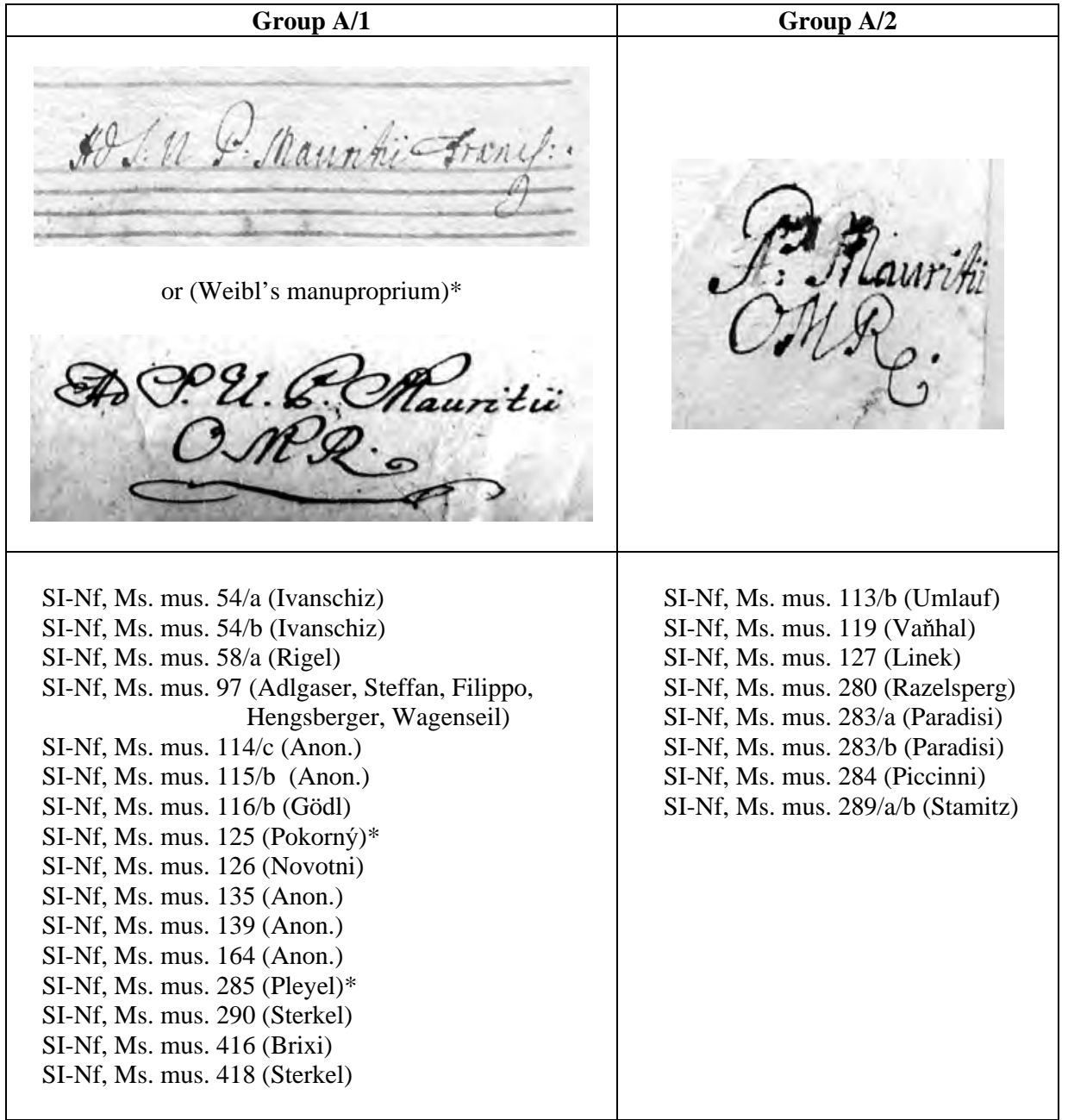

Table 2

\begin{tabular}{|l|l|l|l|}
\hline \multicolumn{5}{|c|}{ Group C } \\
\hline SI-Nf, Ms. mus. 94 & SI-Nf, Ms. mus. 122/b & SI-Nf, Ms. mus. 148 & SI-Nf, Ms. mus. 446 \\
SI-Nf, Ms. mus. 99 & SI-Nf, Ms. mus. 136 & SI-Nf, Ms. mus. 149 & SI-Nf, Ms. mus. 452 \\
SI-Nf, Ms. mus. 100 & SI-Nf, Ms. mus. 137 & SI-Nf, Ms. mus. 165 & SI-Nf, Ms. mus. 455 \\
SI-Nf, Ms. mus. 113/a & SI-Nf, Ms. mus. 142 & SI-Nf, Ms. mus. 167 & SI-Nf, Ms. mus. 464 \\
SI-Nf, Ms. mus. 115/c & SI-Nf, Ms. mus. 143 & SI-Nf, Ms. mus. 168 & SI-Nf, Ms. mus. 489 \\
SI-Nf, Ms. mus. 122/a & SI-Nf, Ms. mus. 146 & SI-Nf, Ms. mus. 231 & SI-Nf, Ms. mus. 511 \\
\hline
\end{tabular}


Table 3

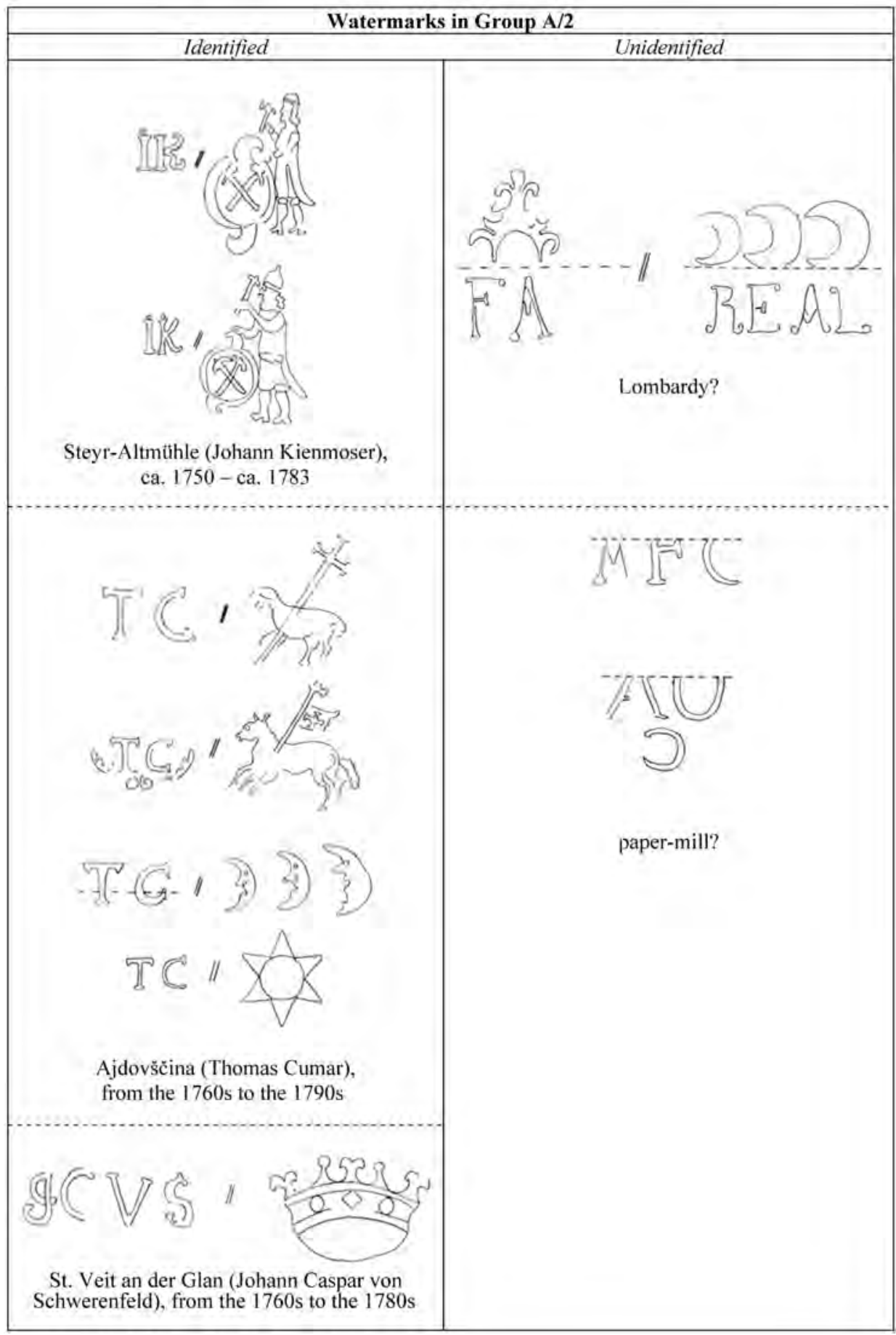


Table 4

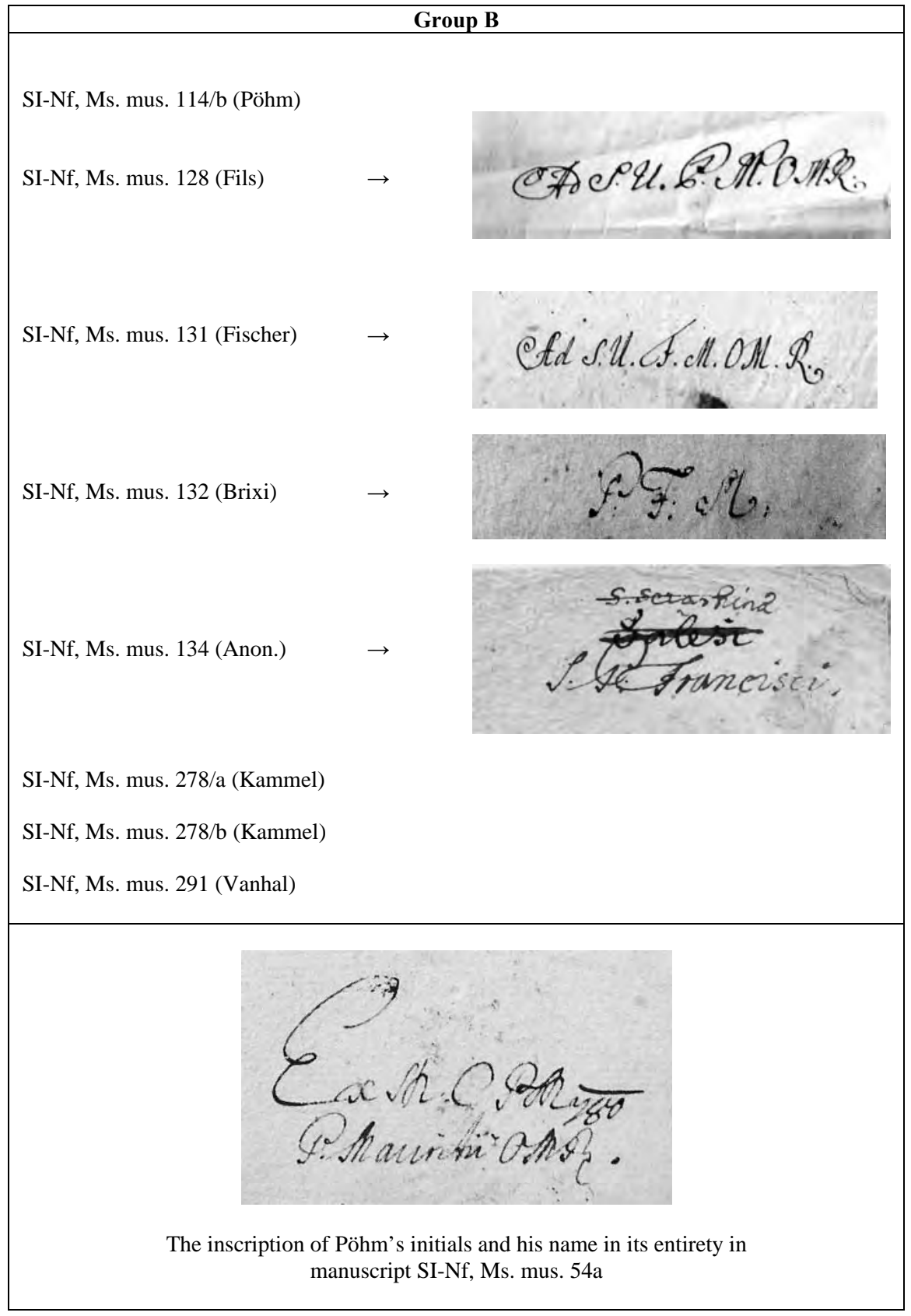


Table 5

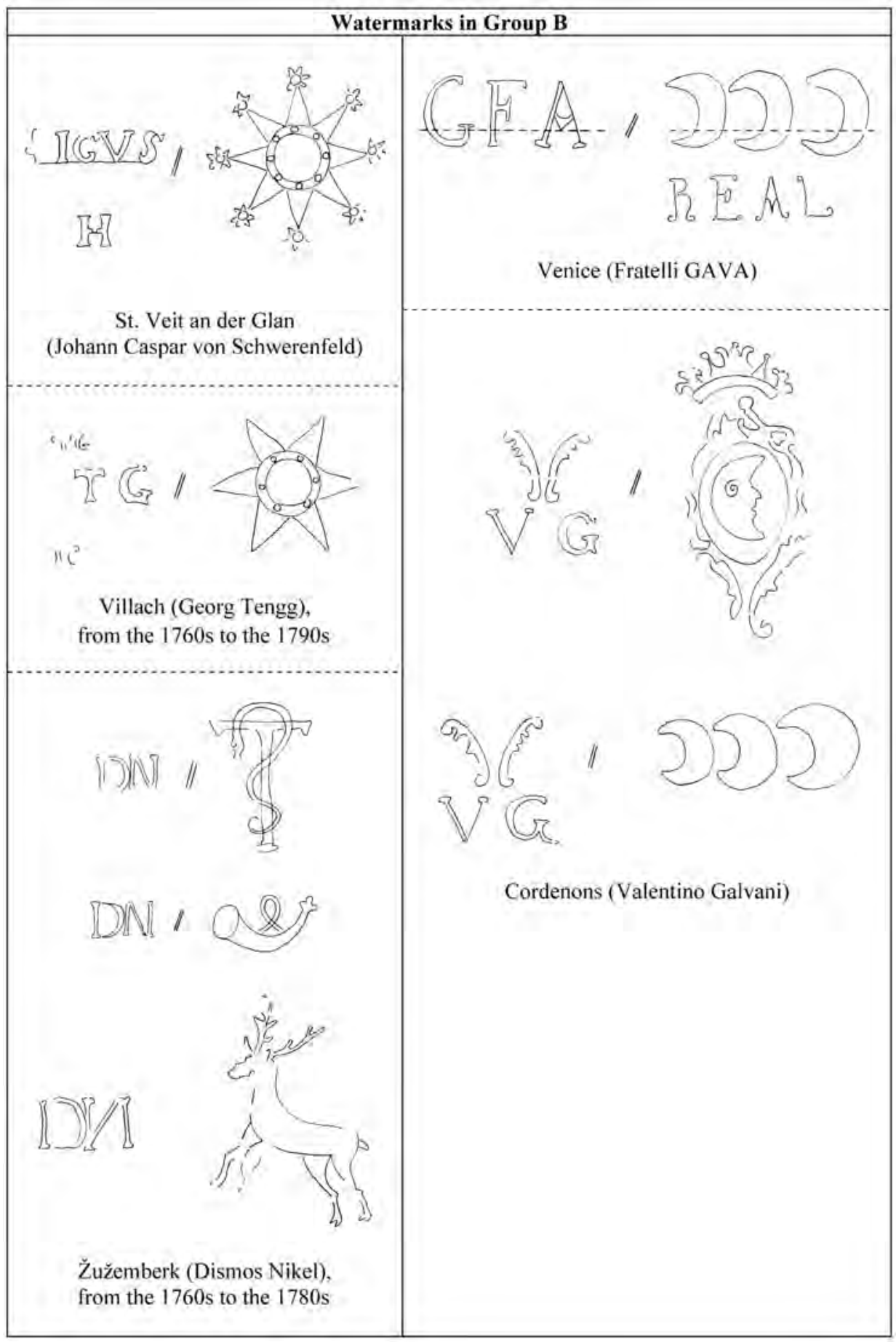


Table 6

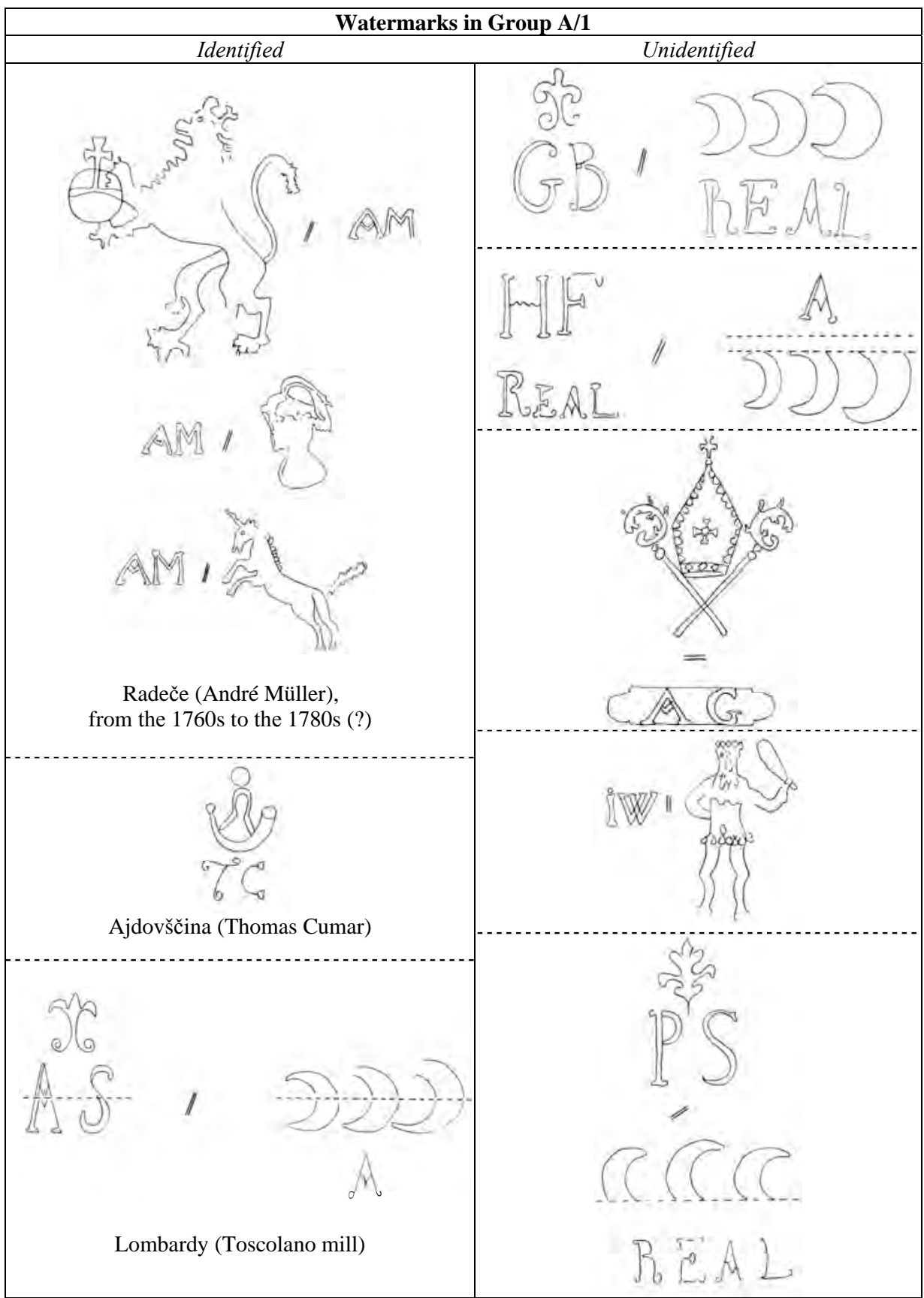


Table 7a

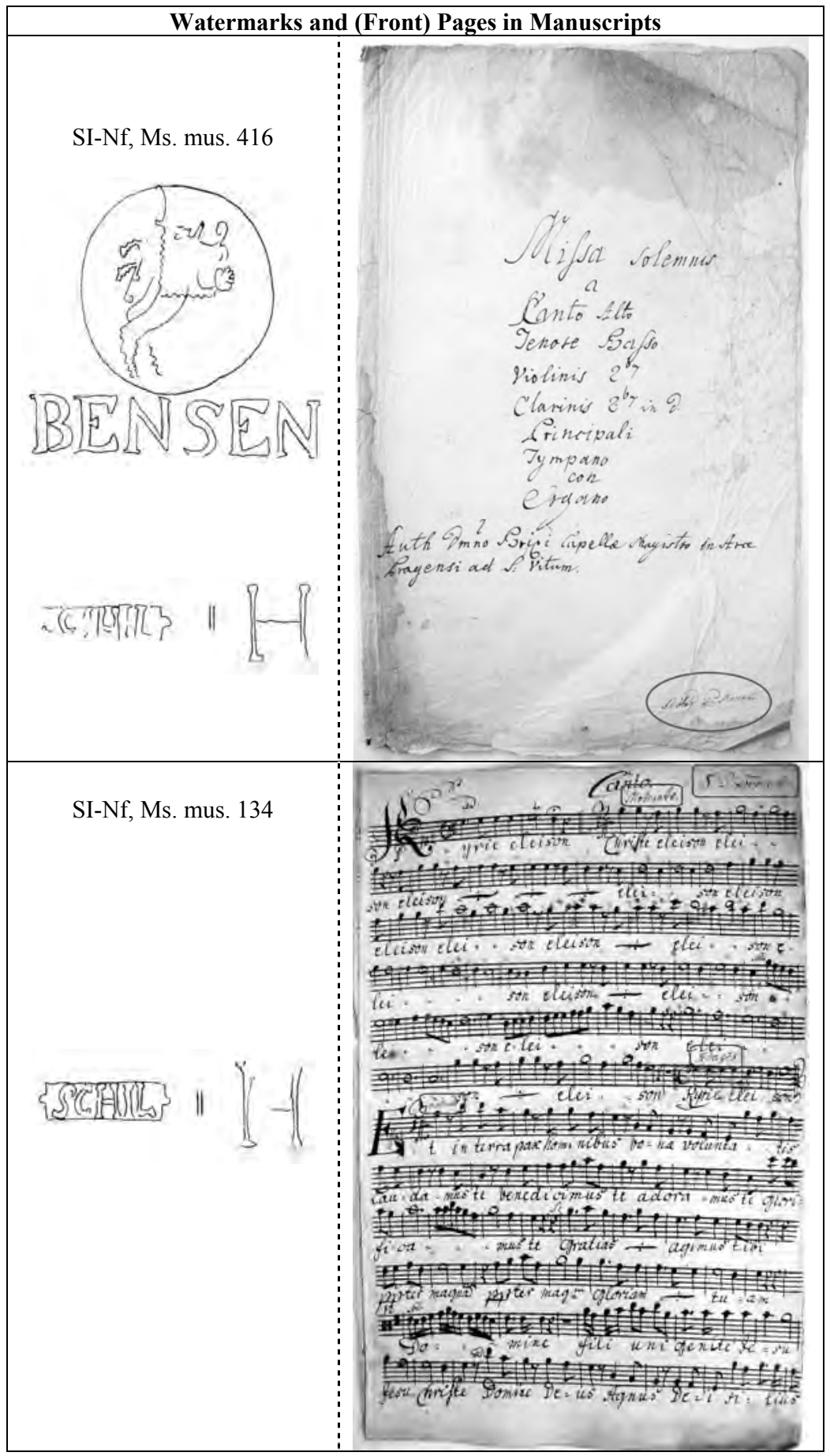


Table 7b

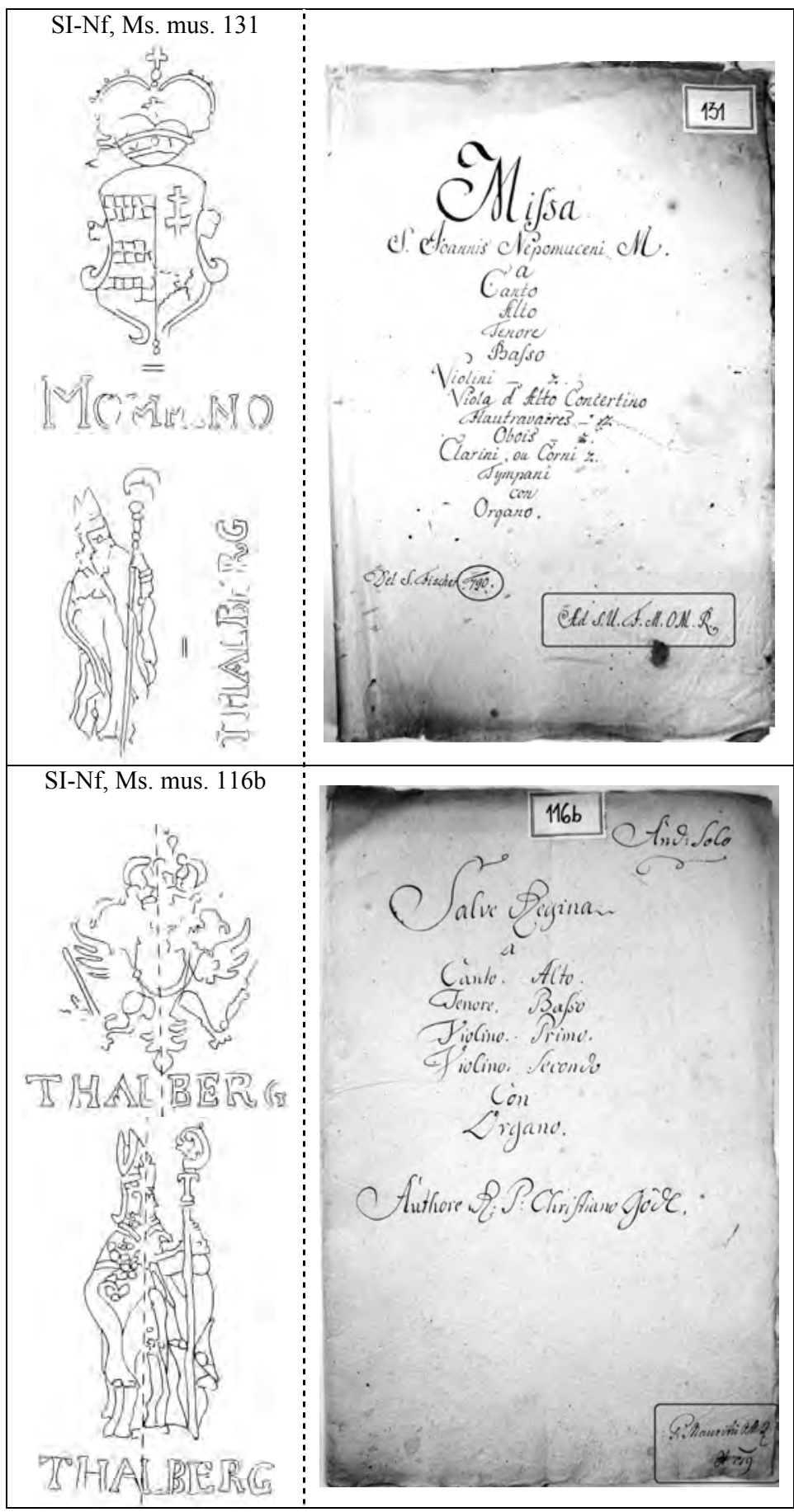




\section{Table 8}

\section{Watermarks in Mauscript SI-Nf, Ms.mus. 285}

First layer: Viola part (unknown writer)

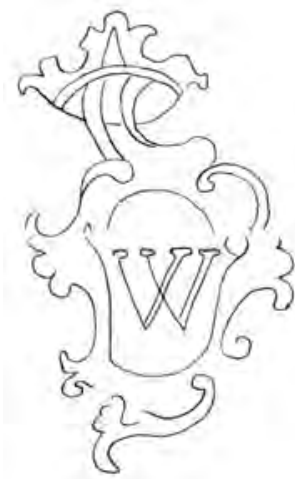

Second layer: front-page (Weibl's handwriting)

Violino Primo, Violino Secondo and Basso parts (Weibl's handwriting)
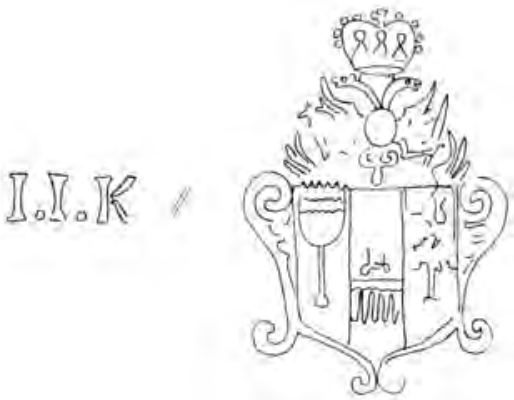

Third layer: Violin Primo and Violino Secondo parts (? Pöhm's subsequent copies)
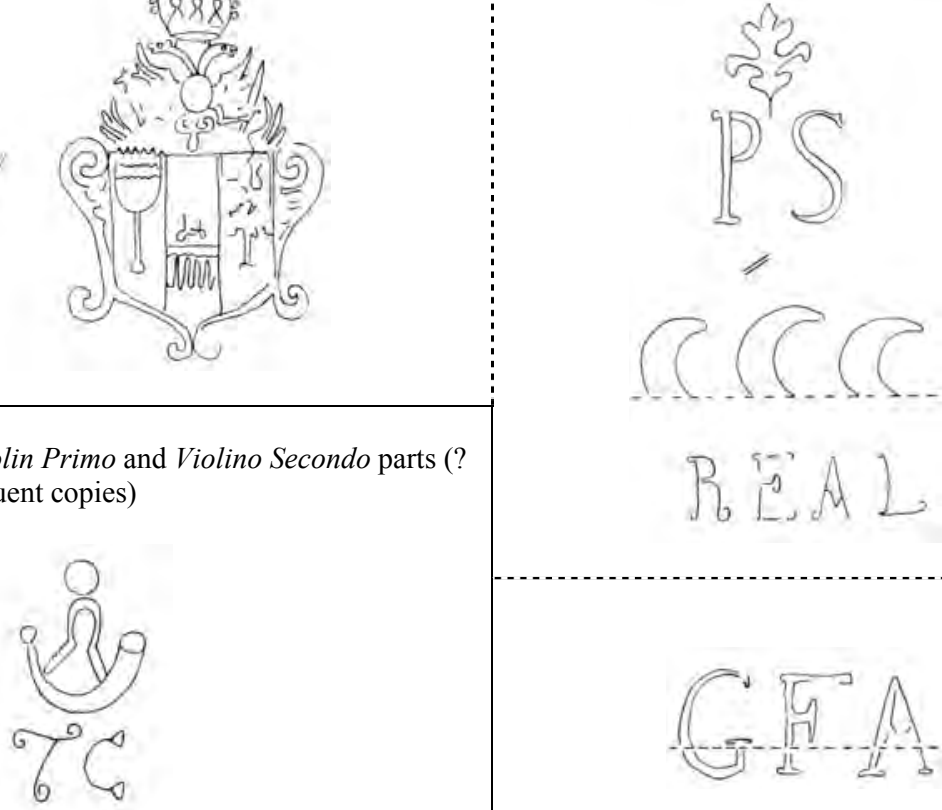


\section{Bibliography}

Barbo, Matjaž. “'Cantual' brežiškega frančiškanskega samostana.” In S patri smo si bili dobri: tri stoletja brežiških frančiškanov, edited by Jože Škofljanec, 257 -273. Krško: Zavod Neviodium; Ljubljana: Brat Frančišek, 2013.

Eineder, Georg. The Ancient Paper-Mills of the Former Austro-Hungarian Empire and Their Watermarks. Monumenta chartae papyricae historiam illustrantia 8. Hilversum: Paper Publications Society, 1960.

Faganel, Tomaž. "Glasbeni repertoar na Slovenskem v 18. stoletju in v prvi polovici 19. stoletja.” In 300 let/Years: Academia Philharmonicum Labacensium 1701-2001, edited by Ivan Klemenčič, 119-130. Ljubljana: Založba ZRC, 2004.

Höfler, Janez. "Glasbenozgodovinske najdbe XVIII. in XIX. stoletja v Novem mestu." Kronika 15, no. 3 (1967): 135-148.

Kinderić, Petar Antun. Franjevci uz orgulje. Krapina: Hrvatsko društvo crkvenih glazbenika, 2006.

Škrjanc, Radovan. "Prispevek k poznavanju repertoarja starejših muzikalij cerkvene glasbe v Sloveniji." Pt. 2. De musica disserenda 2, no. 1 (2006): 31-60.

___ . "Prispevek k dataciji rokopisov skladb Jakoba Frančiška Zupana," Muzikološki zbornik 34 (1998): 35-68.

Šorn, Jože. "Starejši mlini za papir na Slovenskem," Zgodovinski časopis 8, nos. 1-4 (1954): 87-117.

Tyson, Alan. "Paper Studies and Haydn: What Needs to be Done," In Joseph Haydn: Bericht über den internationalen Joseph Haydn Kongress (Wien, Hofburg, 5.-12. September 1982), edited by Eva Badura-Skoda, 577-592. Munich: Henle, 1986.

Wiesmüller, Beate. "The Watermarks from the Refaiya-Library." http://www.refaiya. uni-leipzig.de/texts/Watermarks_Refaiya.pdf. 


\section{P. MAVRICIJ PÖHM IN NJEGOVA VLOGA PRI OBLIKOVANJU GLASBENEGA REPERTOARJA V NOVEM MESTU V DRUGI POLOVICI 18. STOLETJA}

\section{Povzetek}

Dosedanje mnenje o odločilni vlogi p. Mavricija Pöhma pri nastanku glasbenega repertoarja, ki se je iz druge polovice 18. stoletja ohranil v Novem mestu, velja najbrž samo deloma oz. le toliko, kolikor v Pöhmu vidi osebo, ki je tamkajšnji frančiškanski samostan oskrbela s številnimi prepisi skladb takrat aktualnih skladateljev iz nekdanjega avstrijskega in širšega evropskega prostora. Manj verjetno pa je, da bi Pöhm večino teh prepisov prinesel s Češkega že ob svojem prihodu v Novo mesto okoli leta 1770. Med mnogimi rokopisi pri novomeških frančiškanih, ki vsebujejo zaznamek o Pöhmovem lastništvu not in jih je zato mogoče neposredneje povezovati s p. Pöhmom, v resnici prevladujejo takšni, ki so napisani bodisi na papirju domačega izvora (v mlinih Dizme Nikla v Žužemberku, Andreja Müllerja v Radečah in Tomaža Kumarja v Ajdovščini) bodisi na papirju, ki je takrat k nam dotekal v večjih količinah s sosednje Koroške (tj. iz mlinov Johanna Casparja von Schwerenfelda v Šentvidu ob Glini in Georga Tengga v Beljaku), pa tudi iz bolj oddaljenega gornjeavstrijskega mlina »Steyr-Altmühle«. Nekatere med temi rokopisi je skoraj zanesljivo deloma ali v celoti napisala prav Pöhmova roka. Nekaj pa je takšnih, ki jih ni izdelal Pöhm in so bili le v njegovi rabi (»Ad S[implicem] U[sum] P. Mauritii OMR «) - npr. ti, ki so sprva pripadli zdaj še neznanemu tedanjemu (novomeškemu?) kopistu Andreju Pittru in imajo čez izbrisano Pittrovo ime zapisan tak zaznamek.

Po drugi strani pa je med »Pöhmovimi rokopisi« v Novem mestu tudi nekaj takšnih, ki vsebujejo papir iz bolj oddaljenih krajev srednje Evrope. Tu sta zlasti zanimiva rokopisa SI-Nf, Ms. mus. 97 in 416, ki oba vsebujeta tudi krajše zaznamke p. Pöhma. Prvi rokopis, gre za zbirko klavirskih skladb več avstrijskih skladateljev, delujočih v desetletjih okrog sredine 18. stoletja, je najverjetneje nastal v kateri od tedanjih dunajskih kopističnih delavnic; drugi - z Brixijevo mašo v C-duru - pa je napisan na papirju češkega izvora in je verjetno nastal že v času, ko je Pöhm še prebival v rodni Češki. Rokopis SI-Nf, Ms. mus. 131, ki je bil nekoč prav tako v lasti p. Pöhma in ga je sicer najverjetneje izdelal njegov kolega p. Kalist Weibl okoli leta 1790, vsebuje poleg znaka z gornještajerskega mlina Thalberg še vodni znak z Moravskega. Thalbergovi znamenji vsebuje tudi rokopis SI-Nf, Ms. mus. 116b. Tega je izdelala neka druga roka, v Pöhmovo last pa je kot kaže prešel leta 1779. Rokopis SI-Nf, Ms. mus. 278c vsebuje beneški papir bratov Gava, rokopis SI-Nf, Ms. mus. 114b - z edino ohranjeno skladbo v Novem mestu, ki bi lahko bila Pöhmova - pa vodni znak Galvanijevega mlina v Cordenonsu.

Zaradi vsega tega in zlasti stikov, ki jih je Pöhm gojil z drugimi glasbeniki že pred prispetjem $v$ Novo mesto in po njem in so zagotovo vplivali na njegov glasbeni okus ter izbiro glasbenega repertoarja za izvajanje na koru novomeškega samostana, postaja tudi Pöhmov življenjepis pomembna tema za prihodnje raziskave glasbenega življenja in repertoarja v Novem mestu iz obdobja 18. stoletja. 